\title{
Ideology vs context in the neoliberal state's management of remote Indigenous housing reform
}

\author{
Daphne Habibis
}

\section{Introduction}

Reforms to the delivery of housing services to remote Aboriginal communities in Australia have resulted in radical changes to housing management. Commencing in 2008, the National Partnership Agreement on Remote Aboriginal Housing (NPARIH) was a 10-year, AU\$5.5-billion housing management and capital works program of new housing, and refurbishment of existing housing, in remote Indigenous communities. As well as increasing the quality and quantity of housing stock, the reforms included the transfer of housing from Indigenous Community Housing Organisations (ICHOs) to state and territory governments, with the goal of improving the standard of housing and housing maintenance by bringing tenancy management up to public housing standards (COAG 2008).

Drawing on Sanders' (2009) framework for analysing policy principles in Australian Indigenous affairs, this chapter argues that as the process of implementing NPARIH rolled out, remote housing delivery became a site in which competing policy principles of guardianship, equality and choice were played out. Equality was evident in NPARIH's goal of 
normalising remote Aboriginal communities so that housing standards are comparable to those that apply in other regions of Australia. There were also elements of adaptation that resulted in some principles of choice and recognition. But these tendencies were accompanied by coercive measures that reflect policy principles of guardianship: first, in their requirement for Aboriginal people to give up some of their land rights by agreeing to government leases over their land; and second, in the emphasis on individual behavioural change and self-responsibility in meeting the same tenancy obligations as apply in mainstream public housing.

The analysis concludes that, despite evidence that an adaptive approach that recognises Aboriginal lifeworlds works best in Aboriginal service delivery, the normalising imperatives of the neoliberal state overwhelmingly support the continuation of the colonising project and the transformation of remote Aboriginal Australia along white 'settler' lines. As argued by others in this volume (Eatock, Chapter 3, Sanders, Chapter 6, HowardWagner, Chapter 12), this shows that although neoliberal governance may allow some lacunas of difference, it is fundamentally aligned with the overarching, enduring and continuing project of colonisation.

\section{Policy tensions within Aboriginal affairs}

Sanders' account of the history of Australian Indigenous affairs argues it involves a triangular relationship between three policy principles of equality, guardianship and self-determination. These compete for dominance, and although one principle may be dominant for decades, it always exists in tension with the other two (Sanders 2009). Equality forms the top apex of the schema, with equality of opportunity the most dominant form, although both socio-economic and legal equality are significant. Sitting on the bottom right corner of the triangle is the principle of guardianship. This operates when 'governments believe that particular people within their jurisdictions are not competent judges of their own best interests' (2009: 8). This involves top-down, paternalistic policies that may include elements of coercion. At the bottom left corner is the principle of choice, in which there is an emphasis on difference and diversity, individual and collective agency and forms of self-determination. Each of these principles contains problematic elements. Equality tends to deny the significance of difference and diversity, guardianship operates 
with a negative understanding of difference and ignores the significance of freedom and choice, while choice may lead to white exploitation of Aboriginal people or negative constructions of Aboriginal agency (ibid.).

Looked at through the lens of neoliberalism, these three principles can be understood in terms of neoliberal goals to eradicate difference through the assimilation and normalisation of communities (equality), to reduce dependence on the state through the regulation of the poor via paternalistic and disciplinary measures (guardianship), and to encourage the creation of self-determining citizens who are empowered to operate as free agents within the market (choice).

Sanders shows that although these principles are partly aligned to the political positions of left and right, they cannot be reduced to these, with both political perspectives embracing elements of these principles, depending on whether industrial society is viewed with enthusiasm or scepticism. Further, although the dominance of particular policy principles map broadly onto the major Indigenous public policy eras of protection, assimilation and self-determination, at any one time, all three principles are in play.

This framework provides a helpful schema for understanding the trajectory of remote Indigenous housing policy, and is used in this chapter to argue that, since 2007, equality and guardianship have been the prevailing policy principles operating in remote Indigenous housing, with equality understood in individualistic terms as equality of opportunity. However, their dominance has not entirely silenced the principle of choice, with jurisdictions applying some adaptive measures that recognise the collective principles that underpin Aboriginal lifeworlds and their embedded and enduring nature.

\section{Methods}

The data for this analysis comes from two Australian Housing and Urban Research Institute-funded investigations into NPARIH undertaken between 2013 and 2015. The first investigated how these reforms were progressing, what forms the new arrangements were taking and what factors influenced these decisions (Habibis et al. 2014); the second examined how well the new arrangements were working (Habibis et al. 2016). 
The study used a mixed-methods approach, involving five case studies undertaken at Ngukkur in the Northern Territory; Mimili, Amata and Pipalyatjara, in the Anangu Pitjantjatjara Yankunytjatjara (APY) Lands of South Australia; Bayulu and Yakanarra in the Fitzroy Valley in Western Australia and at communities in and around Kununurra in Western Australia; and at Wujal Wujal and Hope Vale in the Cooktown region of Queensland (see Figure 9.1).

Across the case studies, a total of 144 tenant surveys, 138 tenant interviews, 37 housing provider interviews and 34 stakeholder interviews were undertaken (see Table 9.1).

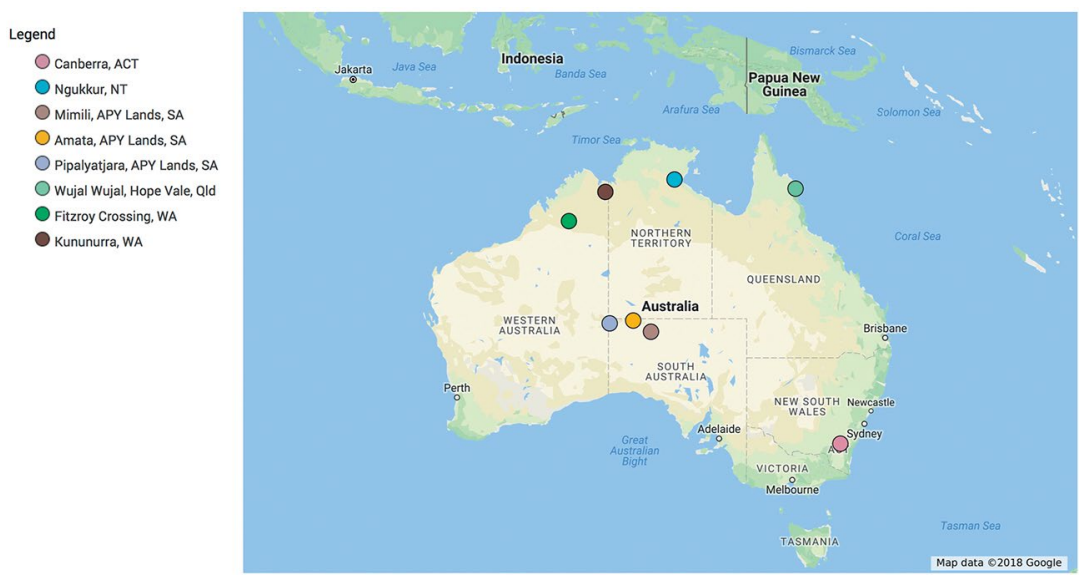

Figure 9.1: Remote tenancies case study communities

Source: Author's extrapolation of data from Google Maps.

The data collection period for each case study site was three weeks, undertaken in blocks of one to two weeks in 2014.

\section{Policy principles in the evolution of Australia's remote Indigenous housing programs}

NPARIH can be understood as the culmination of a shift in Aboriginal housing policy that commenced in the 1990s in which principles of choice and self-determination were replaced by those of equality and guardianship. From this time, in urban settings, state-owned and managed Indigenous housing was increasingly integrated into mainstream public housing programs (see Milligan et al. 2016: 76-8). But, in remote communities, 
Indigenous housing remained under the control of ICHOs, which had first emerged in the late 1960s under policies of self-determination. These Aboriginal-controlled organisations were funded by the Community Housing Infrastructure Program (CHIP), which was managed by the Aboriginal and Torres Strait Islander Commission (ATSIC). Following the dismantling of ATSIC in 2004, responsibility for CHIP was transferred to the Australian Government Department of Families, Housing, Community Services and Indigenous Affairs (FaHCSIA). In 2007, an Australian Government-initiated review of CHIP found that the program was failing to provide adequate housing for remote-living Indigenous people and recommended its abolition and replacement with a program managed by state housing authorities (FaHCSIA 2007). This coincided with the Northern Territory Emergency Response (NTER), in which media and public policy constructed remote Aboriginal communities as universally chaotic and dysfunctional, and in need of government regulation and control (Proudfoot \& Habibis 2015). This justified the introduction of a guardianship approach to housing management on remote Aboriginal communities in the Northern Territory, including the transfer of remote Aboriginal housing management from the ICHO sector to Territory Housing and the imposition of compulsory 99-year leases over prescribed Northern Territory communities.

Table 9.1: Case study field visits: Respondent numbers

\begin{tabular}{|l|l|r|}
\hline \multicolumn{2}{|l|}{ Respondents } & N \\
\hline All & Survey & 144 \\
\cline { 2 - 3 } & Interview & 138 \\
\hline Housing provider & Interview & 37 \\
\hline Stakeholders & Interview & 34 \\
\hline Ngukkur, Northern Territory & \multicolumn{2}{|l|}{} \\
\hline Tenants & Survey & 30 \\
\cline { 2 - 3 } & Interview & 29 \\
\hline Housing provider & Interview & 6 \\
\hline Stakeholders & Interview & 8 \\
\hline Cooktown region, Queensland & & 30 \\
\hline Tenants & Survey & 23 \\
\cline { 2 - 3 } & Interview & 5 \\
\hline Housing provider & Interview & 7 \\
\hline Stakeholders & Interview & \\
\hline
\end{tabular}




\begin{tabular}{|l|l|r|}
\hline \multicolumn{2}{|l|}{ Respondents } & N \\
\hline APY Lands, South Australia & Survey & 29 \\
\cline { 2 - 3 } & Interview & 28 \\
\hline Tenants & Interview & 9 \\
\hline Housing provider & Interview & 4 \\
\hline Stakeholders & & 29 \\
\hline Fitzroy Valley, Western Australia & Survey & 33 \\
\hline Tenants & Interview & 11 \\
\hline Housing provider & Interview & 12 \\
\hline Stakeholders & Interview & \\
\hline Kununurra and surrounds, Western & Australia & 26 \\
\hline Tenants & Survey & 25 \\
\cline { 2 - 3 } & Interview & 6 \\
\hline Housing provider & Interview & 3 \\
\hline Stakeholders & Interview & \\
\hline
\end{tabular}

Source: Habibis et al. $(2014,2016)$.

Some of the authoritarian elements of the NTER were included in NPARIH when it was introduced to all states and the Northern Territory the following year. Government investment in housing infrastructure was only available if the owners of Aboriginal land agreed to lease their land to the states and the Northern Territory, while tenants were required to meet behavioural requirements through regularised tenancy agreements that included paying rent at public housing settings, maintaining their homes to public housing standards and meeting obligations for good behaviour.

There were also elements of equality within NPARIH because of its concern to improve living standards for remote-living Aboriginal people by bringing a systemic approach to remote tenancy and property management and to establish a uniformity of housing standards across remote communities that were the same as those that applied in other parts of Australia (COAG 2008). Under ICHO management, few tenants were protected by Residential Tenancies Act (RTA) legislation. Inadequate resources and structural problems relating to the small size of most ICHOs, as well as a lack of housing management skills within the sector, had meant many tenants had paid little or no rent, reducing already inadequate funding for housing maintenance. Consequently, this was often minimal (Eringa et al. 2009). NPARIH addressed this by requiring 
state housing agencies to ensure compliance with RTA legislation, to introduce effective repairs and maintenance regimes and to apply rent payment regimes in line with those in public housing.

This imposition of a public housing model on remote Aboriginal communities reflects the neoliberal state's modernising imperative and its emphasis on the normalisation of cultural and geographic difference. With important exceptions, there was little attempt to adapt this model to the kin-based nature of remote Aboriginal communities, and the collective norms that underpin daily life. Despite its being developed in vastly different urban contexts, most state and territory housing managers assumed that NPARIH should be implemented as a centralised, onesize-fits-all program, little different from mainstream public housing program and policy settings. This was in tension with elements of the National Partnership Agreements that supported a degree of choice and self-determination, and was also impractical and inefficient when it came to implementation.

\section{Ideology vs context in the implementation of NPARIH}

NPARIH was a top-down policy intervention, developed in Canberra with minimal consultation with Aboriginal people, including those it directly affected. It contributed substantially to the decline of the ICHO sector, with the number of organisations falling nationally from 496 in 2006 to 330 in 2012 (Habibis et al. 2016: 20), weakening one of the main avenues for Aboriginal choice and self-determination. From the perspective of governance theory, this willingness to deny Aboriginal agency can be understood as deriving from the view that Aboriginal people, being outside the market economy, are therefore in need of pedagogical discipline (see also Altman \& Hinkson 2007, Ford \& Rowse 2012, Howard-Wagner 2012, Strakosch 2015). While authoritarian and coercive measures are not necessary for those subject to the normalising impact of the labour market, this is not the case for those who stand outside it. Instead, such citizens may be subject to special measures to encourage greater autonomy and self-regulation, and a reduction in dependence on the state (Helliwell \& Hindess 2002). 
The changes expected of tenants under the regulatory regimes of government housing agencies were considerable. Under ICHO management, most tenants had paid little or no rent, maintenance regimes were minimal or non-existent, property damage was not penalised, and because housing was usually on Aboriginal land, the distinction between ownership and renting was blurred. Housing decisions, such as allocations and transfers, were mostly undertaken locally, through informal consultation with family and community. This was vastly different from the formal, centralised policy practices of government housing agencies.

But if NPARIH represented a radical change for Aboriginal people, it was also challenging for the states and the Northern Territory, where it was imposed by the Australian Government in a rapid policy shift. In the Northern Territory, the government housing agency's housing portfolio doubled, virtually overnight, from 5,000 to 10,000 , with many remote community properties in a deteriorated condition (Habibis et al. 2016). Within state and territory housing agencies, the skills and capacity to manage Aboriginal housing was limited, as these had been largely lost following the mainstreaming of Aboriginal housing that had occurred in the urban sector over the previous two decades.

These difficulties were compounded by the conditions of housing delivery in remote communities (Memmott et al. 2003, Milligan et al. 2011, Habibis 2013, Habibis et al. 2014). In most remote Aboriginal communities, there is no housing market, so constructs such as 'market rent' and 'housing market' do not apply. The collective nature of Indigenous land tenure meant that, in most locations, residential tenancy legislation had to be altered before it could apply, and native title considerations and limited or non-existent service infrastructure restricted where buildings could be located.

The delivery of housing services is also impacted by distance, the absence of a skilled workforce, poor transport structure and the often harsh terrain and weather conditions, making everything more costly. Communities are often located many kilometres from service centres, with unsealed roads that are dangerous and difficult to travel. This creates occupational health and safety and practical challenges, impacts on staff time and makes it difficult to establish local offices and to recruit, oversee and support community-based staff. Limited mobile and internet coverage make establishing effective communication systems difficult. Repairs and maintenance are constrained by a low rent base, extreme 
weather events and expensive contractor services. Travel times can rapidly blow-out a community's repairs and maintenance budget and distances make accurate scoping of jobs and monitoring and regulation of suppliers challenging.

Remote Indigenous populations are also very different from urban populations. Communities are mostly comprised of extended families and other kin, households are large and comprised of multi-family households. This, together with a shortage of housing, creates high levels of crowding, which generates costly repairs and maintenance needs. Frequent population movement between houses and communities makes identifying occupants and collecting rent difficult. Residents of communities often have low skills and educational achievement, high levels of disability, and language and cultural differences.

Given these differences, it is hard to understand why most states and the Northern Territory provided their services through a model designed for white, urban populations that was poorly aligned with the population needs and the conditions that operated in remote communities. Explanations include a politicised context following the controversy that surrounded the NTER and the failures of the capital works program that followed it (the Strategic Indigenous Housing Infrastructure Program). This generated federal government pressure on the states to rush policy implementation, so there was little time to develop innovative policies that were appropriately calibrated to the conditions. In some states, there was a strong ideological commitment to mainstreamed service delivery as more cost-effective and efficient, as well as an assumption within many of the states and the Northern Territory that, following the experience with CHIP, services should be provided directly (Habibis et al. 2014). It was also the case that, in some locations, there was no alternative organisation with the skills and capacity to provide housing services.

In South Australia, the Northern Territory and Queensland, service delivery was largely centralised with little adjustment to local conditions. For example, in Queensland, despite language differences, and most houses not having a street address, tenants notified repairs and maintenance requirements via a blue phone connected to the public housing statewide call centre. In all locations, despite the high cost of living in remote communities, and the high level of poverty, rent settings were designed to gradually increase until they were the same as applied in urban settings. 
But within these predominantly mainstreamed models of housing service delivery, there were some elements of choice and recognition. NPARIH policy required leases to be voluntary and for community consultation to occur. South Australia's rent model was initially in line with the 'chuckin' system that had prevailed under ICHO management (Eringa et al. 2009), with per capita rents applied to all adult tenants. Eligibility for housing was also treated as a largely community matter, with criteria related to kin and language. For this reason, there were no caps on income eligibility (Habibis et al. 2014: 40-1). In the Northern Territory, some Indigenous organisations, as well as shire councils, were used for some aspects of tenancy management in some regional centres and town camps. Similarly, in Queensland, the Department of Housing contracted some Indigenous shire councils to deliver some housing services. The jurisdiction where choice and recognition were most evident was Western Australia, where there were six regions in which the housing department established a hybrid service delivery arrangement, in which five ICHOs and a community housing provider were contracted to manage housing. It also developed a consultation strategy involving clear protocols that ensured investment and engagement by both parties and inclusion of community priorities.

\section{How well did NPARIH work?}

What do the findings suggest about how well these arrangements worked? Overall, they show that NPARIH went a considerable way in establishing public housing-like standards in some remote Indigenous communities, and there were improvements in the lives of tenants where NPARIH investments took place (see Habibis et al. 2016: 44-98 for a detailed presentation of the findings). Most tenants who participated in our study agreed that housing and living conditions had improved and that overall things in the community were better. Respondents understood key aspects of their tenancy agreement and were keen to maintain their new and refurbished homes in good condition. But there were many areas that required improvement, including allocations, tenant support programs, tenants' understanding of their rights and timely information about rent arrears. Crowding remained high in many locations, especially the Northern Territory and South Australia. There were problems of fairness and efficiency in the application of mainstream rent settings, and centralised repairs and maintenance systems were slow and 
inefficient. Many small communities outside of NPARIH arrangements faced an uncertain future, with no commitment from the states or the Commonwealth to the provision of housing and essential services.

When it came to the question of satisfaction with housing management, overall the response was positive. Figure 9.2 presents survey rating averages for some of these items and shows that among those surveyed, levels of satisfaction were generally quite high ( 5 equals very satisfied; 3 equals neither satisfied nor unsatisfied; 1 equals very unsatisfied), especially in relation to how rent was collected, the quickness of repairs and treatment by housing officers. Satisfaction was lowest in relation to wait times for repairs and maintenance, provision of information about rent payments and the way housing officers responded to complaints.

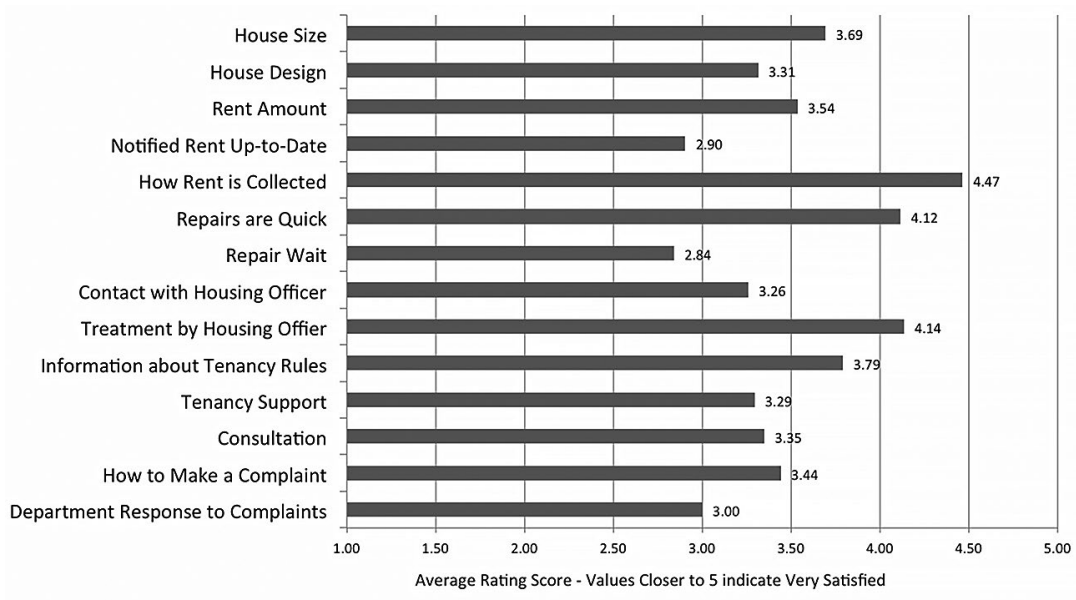

Figure 9.2: Satisfaction with housing and housing management All jurisdictions

Source: Habibis et al. (2014, 2016).

However, analysis by case study location shows substantial differences between jurisdictions in areas including house size and house design, ease of arranging repairs, repair wait times, frequency of contact with housing officers and levels of consultation (see Table 9.2). Satisfaction levels are highest for the Western Australia sites of Fitzroy Crossing and Kununurra and surrounds. This is also the case for views on whether the condition of houses in the community had improved where these two case study sites showed the strongest positive response (Figure 9.3). Across all the data sources, there is a consistent pattern that these locations are operating with the greatest levels of community acceptance and perceptions of 
service quality. While there is insufficient space to provide the detail here, our cost analysis also shows there are significant savings to be made if services can be locally provided (Habibis et al. 2016: 94-7). These findings support other Aboriginal housing research (Milligan et al. 2011, Moran et al. 2016) that housing services to Aboriginal people work best when they are adapted to local contexts, delivered by Aboriginal people and provide strong mechanisms for communication and consultation with tenants and communities.

These findings are based on single case studies, and are influenced by many contextual factors, including the quality and quantity of existing housing, the community's prior experiences of housing management and its distance from service centres. The findings from Ngukkur were affected by high levels of tenant occupancy, with logistic regression of the survey findings showing household density influenced levels of satisfaction (Habibis et al. 2016: 87-90). The Western Australian Government also contributed additional funding to NPARIH, allowing a degree of discretionary investment. But the strength and consistency of the findings suggest the local model of service delivery, with high levels of Aboriginal employment, played an important part in explaining differences in case study results. In both Western Australian case study sites, housing services, including repairs and maintenance were delivered through local partners with high numbers of Indigenous employees. At Fitzroy Crossing, the partner was a large, relatively well-resourced ICHO that had been delivering housing services in the pre-NPARIH era whose staff was almost entirely Indigenous. In Kununurra, the partner was Community Housing Limited, which employed local Aboriginal staff who were well regarded and trusted in the communities. The Western Australia Department of Housing took a capacity-building approach to working with its partners, supporting them to develop their IT systems, seconding staff experienced in working with Aboriginal tenants and establishing specialist positions to support compliance.

This approach contrasted with the other case study communities where services were delivered in a largely centralised, non-adaptive way. In Queensland's Cooktown communities, there was no local office; instead, services were provided on a drive-in, drive-out basis, repairs and maintenance were centralised and there was a siloed approach to tenancy, maintenance, procurement and asset management. Little attention was paid to tenant support, education or community engagement. In Ngukkur, levels of local control and employment were low and there was little provision of tenant education and support. 
Table 9.2: Comparison of rating averages of satisfaction levels with housing and housing management

\begin{tabular}{|l|r|r|r|r|r|}
\hline Item & NT & Qld & SA & WA-FC & WA-K \\
\hline House size & 3.89 & 3.32 & 2.73 & 4.43 & 4.15 \\
\hline House design & 2.63 & 3.21 & 2.82 & 4.07 & 4.07 \\
\hline Rent amount & 3.35 & 3.75 & 3.14 & 3.80 & 3.58 \\
\hline How easy arrange repairs & 3.63 & 3.88 & 3.55 & 4.54 & 4.80 \\
\hline Repair wait time & 2.07 & 2.92 & 2.28 & 3.26 & 3.80 \\
\hline How often see housing officer & 3.60 & 3.04 & 2.55 & 2.93 & 3.96 \\
\hline How treated by housing officer & 4.03 & 4.00 & 3.93 & 4.22 & 4.35 \\
\hline Information about tenancy rules & 3.42 & 3.36 & 3.67 & 4.31 & 4.16 \\
\hline Tenancy support & 2.96 & 3.33 & 3.14 & 3.73 & 3.24 \\
\hline How well consulted & 2.82 & 2.53 & 3.92 & 3.74 & 3.63 \\
\hline
\end{tabular}

Source: Habibis et al. (2014, 2016).

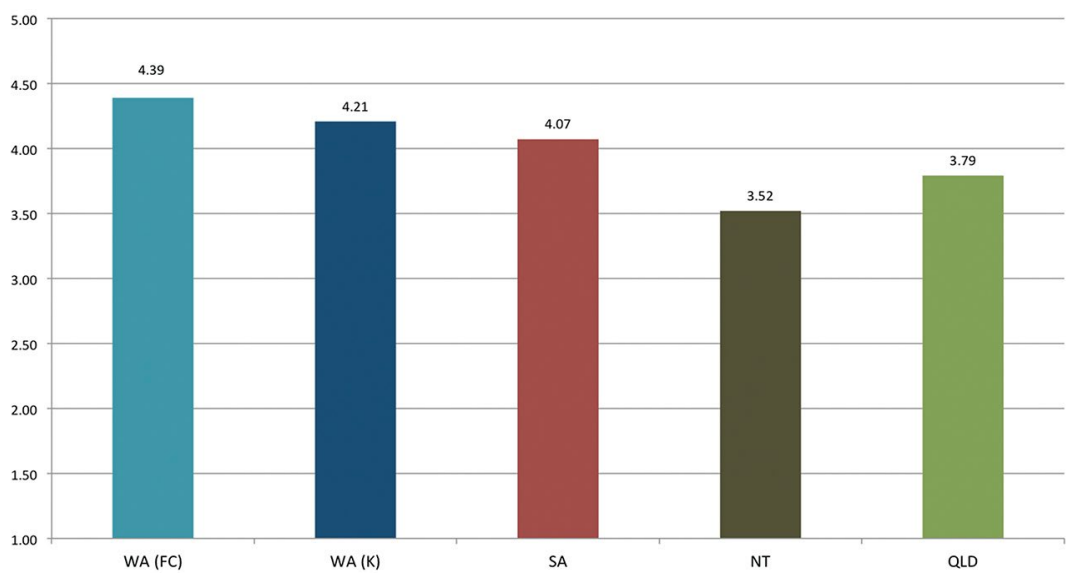

Figure 9.3: Rating averages of improvements in housing conditions Source: Habibis et al. (2014, 2016).

\section{Beyond NPARIH: Another policy punctuation or the continuation of mainstreaming?}

NPARIH amounted to a radical experiment in managing housing on remote Indigenous communities. It was the first time that the states and the Northern Territory had taken on these responsibilities and it took time for services to be established. The early years of the program 
focused on capital works, and it was only once these were underway that attention shifted to tenancy management (Habibis et al. 2014). As the new systems became established there were changes to some arrangements (see Habibis et al. 2016). The Northern Territory developed a local approach to repairs and maintenance; in Queensland, a new regional housing office was established in the Cooktown region to enable local delivery of services. In Western Australia, the housing agency extended its contract to a mainstream community housing provider to provide housing management services in Kalgoorlie, Halls Creek, Exmouth and the Goldfields. In the Ngaanyatjarra Lands, in response to pressure from the local Aboriginal community, it agreed to a rent model closer to arrangements that had applied under ICHO management.

\section{A return to recognition or continuing colonisation?}

This account presents a picture in which the state's goals to normalise remote Aboriginal Australia through policies of guardianship and equality have achieved partial success. In accepting leases over their land-justified in terms of the need to protect the Commonwealth's investment and to ensure the longevity of housing infrastructure (COAG 2008: 5) Aboriginal people have been required to trade hard-won land rights for improvements in services and living conditions that are routinely provided elsewhere. Tenants have similarly accepted the trade-off of new or refurbished homes in return for acceptance of mainstream tenancy obligations. At the same time, the regularisation of housing on remote Aboriginal communities retains elements of choice and recognition through a degree of consultation, some adaptation to local conditions and some limited Aboriginal control over housing management.

To the extent that policy principles of choice in the sense of Aboriginal self-determination have been present, they are arguably due, not so much to any policy commitment to this goal, but to a pragmatic response to the realities of housing service provision in remote communities, where partnering with knowledgeable third-party providers makes sound economic and strategic sense, especially when it includes employment of local Aboriginal people. It is also important to acknowledge Aboriginal resistance to the efforts of the state to normalise remote communities along white settler lines. This can be seen in the survey findings that 
show lower levels of satisfaction with mainstreamed service delivery and an overwhelming preference for housing services to be delivered by community organisations, especially those operated by Aboriginal people (see Habibis et al. 2016: 90-4). Resistance is apparent in the protests to the closure of smaller communities (Howitt \& McLean 2015) and in continuing efforts by Aboriginal organisations to control their own housing services (APONT 2015). In the Northern Territory, Aboriginal pressure has resulted in some commitment to maintain smaller communities, albeit with strict guidelines and funding limits (NT Government 2017), and there are some moves to explore innovative models of housing delivery. It is too early to say what this will deliver, but the history of Aboriginal-state relations in the Northern Territory suggest Aboriginal people's distrust of government bureaucracy, their preference for services to be delivered by Aboriginal people and Aboriginal organisations, and their determination to remain on country, will remain a potent force.

This analysis reveals the capacity of neoliberalism to tolerate small spaces of contestation within a larger trajectory towards the denial of difference and diversity. The overwhelming policy push is for the normalisation of Aboriginal communities as part of the incorporation of Aboriginal people into market society (Howard-Wagner 2012: 5). This is evident in continuing pressure on smaller communities and the concentration of funding in regional communities. The National Partnership on Remote Housing that replaced NPARIH encourages greater mobility of remote residents to better labour markets, increases requirements to enforce mainstream tenancy obligations and recommends the reform of land tenure to allow commercial investment and home ownership (COAG 2016). There is also little to suggest any broad change to the application of mainstream rent settings or substantial moves towards local management and delivery of repairs and maintenance.

Sanders' chapter in this volume points to the importance of retaining the concept of colonisation because of its significance for Indigenous recognition (Sanders this volume, Chapter 6) and elsewhere, Spiers Williams writes of the way neoliberalism complements the objectives of colonialism, boosting its continued trajectory of colonisation (2016: 14). This analysis of reforms to housing in remote Aboriginal Australia supports these arguments, demonstrating that, despite some limited contrary trends towards recognition and self-determination, the overarching trajectory is towards the assimilation of the Indigene whose identity is incompatible with the demands and expectations of the Australian neoliberal state. 
The findings from our study point to the perversities inherent within this agenda. These suggest the most effective and financially efficient arrangement for the delivery of remote Indigenous housing is not one that is standardised and centrally driven, but rather one that supports local economies and communities and that acknowledges rather than eradicates difference. Effective housing in remote Indigenous communities requires adaptive policies that recognise and respect Aboriginal culture and that manage housing through partnerships between governments and local providers. Unfortunately, there is little to suggest the Australian state is listening to the evidence base. The future direction of housing policy to remote Indigenous communities is likely to follow the national direction, in which the influence of new public management is resulting in governments divesting their role in social housing supply and management by increasing the role of the community sector (Pawson et al. 2015). In remote Indigenous housing policy there is no indication that increasing the role of the community sector will include any emphasis on building the ICHO sector, despite the considerable efforts of Aboriginal people to push for more consultation and control. This does not bode well for the future of housing on remote Aboriginal communities, and increases the likelihood that within a decade or so, with the divestment of the state, we will once again witness a housing crisis in remote Aboriginal Australia, at considerable cost to the people who live there.

\section{References}

Altman J \& Hinkson M (eds) (2007). Coercive reconciliation: Stabilise, normalise, exit Aboriginal Australia, Arena Publications, Melbourne.

APONT (Aboriginal Peak Organisations of the Northern Territory) (2015). Aboriginal Remote Housing Forum, 12-13 March, Darwin, www.amsant. org.au/apont/wp-content/uploads/2015/02/APONT-Housing-Forum-1213-March-2015-Report_LOW_RES.pdf.

COAG (Council of Australian Governments) (2008). National Indigenous Reform Agreement (Closing the Gap), www.federalfinancialrelations.gov.au/content/ npa/health/_archive/indigenous-reform/national-agreement_sept_12.pdf.

COAG (2016). National partnership on remote housing, Council on Federal Financial Relations, www.federalfinancialrelations.gov.au/content/npa/ housing.aspx. 
Eringa K, Spring F, Anda M, Memmott P, Long S \& West M (2009). Scoping the capacity of Indigenous community organisations. AHURI Final Report No. 125, Australian Housing and Urban Research Institute, www.ahuri.edu. $\mathrm{au} /$ research/final-reports/ 125 .

FaHCSIA (Families, Housing, Community Services and Indigenous Affairs) (2007). Living in the sunburnt country-Indigenous housing: Findings of the review of the Community Housing and Infrastructure Programme, report prepared by PricewaterhouseCoopers, Department of Families, Community Services and Indigenous Affairs, www.dss.gov.au/sites/default/files/ documents/05_2012/livingsunburntcountry.pdf.

Ford L \& Rowse T (2012). Between settler and Indigenous governance, Routledge, London.

Habibis D (2013). Australian housing policy, misrecognition and Indigenous population mobility. Housing Studies 28(5):764-81, doi.org/10.1080/0267 3037.2013.759545.

Habibis D, Phillips R, Phibbs P \& Verdouw J (2014). Progressing tenancy management reform on remote Indigenous communities, AHURI Final Report No. 223, Australian Housing and Urban Research Institute, Melbourne, www.ahuri.edu.au/research/final-reports/223.

Habibis D, Phillips R, Spinney A, Phibbs P \& Churchill B (2016). Identifying effective arrangements for tenancy management service delivery on remote Indigenous communities, AHURI Final Report No. 271, Australian Housing and Urban Research Institute, Melbourne, www.ahuri.edu.au/research/finalreports/271.

Helliwell C \& Hindess B (2002). The empire of uniformity and the government of subject peoples. Cultural Values 6(1-2):139-42, doi.org/10.1080/ 1362517022019784 .

Howard-Wagner D (2012). Using theory to 'speak back' to neoliberal performativity: The Northern Territory Intervention and the inventing of a neoliberal subject as a case in point. Theorising Indigenous Sociology: Australian Perspectives series, University of Sydney, Sydney.

Howitt R \& McLean J (2015). Towards closure? Coexistence, remoteness and righteousness in Indigenous policy in Australia. Australian Geographer 46(2):137-45, doi.org/10.1080/00049182.2015.1020992.

Memmott P, Long S, Chambers C \& Spring F (2003). Categories of Indigenous 'homeless' people and good practice responses to their needs, AHURI Final Report No. 49, Australian Housing and Urban Research Institute Limited, Melbourne, www.ahuri.edu.au/research/final-reports/49. 
Milligan V, Martin C, Phillips R, Liu E, Pawson H \& Spinney A (2016). Profiling Australia's affordable housing industry, AHURI Final Report No. 268, Australian Housing and Urban Research Institute, Melbourne, doi.org/ 10.18408/ahuri-7108401.

Milligan V, Phillips R, Easthope H, Lui E \& Memmott P (2011). Urban social housing for Aboriginal people and Torres Strait Islanders: Respecting culture and adapting services, AHURI Final Report No. 172, Australian Housing and Urban Research Institute Limited, Melbourne, www.ahuri.edu.au/research/ final-reports/172.

Moran M, Memmott P, Nash D, Birdsall-Jones C, Fantin S, Phillips R \& Habibis D (2016). Indigenous lifeworlds, conditionality and housing outcomes, AHURI Final Report No. 260, Australian Housing and Urban Research Institute, Melbourne, www.ahuri.edu.au/research/final-reports/260.

NT (Northern Territory) Government (2017). Services to remote communities and homelands, Department of Housing and Community Development.

Pawson H, Milligan V, Wiesel I \& Hulse K (2015). Public stock transfers to community housing the best option for a sustainable and financially supportable housing system, AHURI Research and Policy Bulletin No. 184, Australian Housing and Urban Research Institute, Melbourne, www.ahuri.edu.au/ research/research-and-policy-bulletins/184.

Proudfoot F \& Habibis D (2015). Separate worlds: A discourse analysis of mainstream and Indigenous populist print media accounts of the Northern Territory emergency response in 2007. Journal of Sociology 51(2):170-88, doi.org/10.1177/1440783313482368.

Sanders W (2009). Ideology, evidence and competing principles in Australian Indigenous affairs: From Brough to Rudd via Pearson and the NTER, Discussion Paper 289, Centre for Aboriginal Economic and Political Research, The Australian National University, Canberra.

Spiers Williams M (2016). Neoliberalism as 'system upgrade' in Australian colonialism: A story told of two legislative provisions. Paper presented at the Indigenous Rights, Recognition and the State in the Neoliberal Age Conference, The Australian National University, 21-22 November.

Strakosch E (2015). Neoliberal Indigenous policy: Settler colonialism and the 'post-welfare' state, Palgrave Macmillan, New York, doi.org/10.1057/ 9781137405418. 
This text is taken from The Neoliberal State, Recognition and Indigenous Rights: New paternalism to new imaginings, edited by Deirdre Howard-Wagner, Maria Bargh and Isabel AltamiranoJiménez, published 2018 by ANU Press, The Australian National University, Canberra, Australia.

doi.org/10.22459/CAEPR40.07.2018.09 